\title{
PraWo PACJENTA - DZIECKA DO WYRAŻeNIA ZGODY NA UDZIELENIE ŚWIADCZENIA ZDROWOTNEGO
}

\section{Wprowadzenie}

Jednym z fundamentalnych założeń, na którym opiera się współczesny system ochrony zdrowia, a w szczególności relacja pomiędzy pacjentem a osobami wykonującymi zawody medyczne, jest poszanowanie autonomii pacjenta. Autonomia ta oznacza swobodę decydowania o podjęciu, kontynuacji i zakończeniu leczenia, wyborze podmiotu leczniczego, samego lekarza, pielęgniarki, położnej czy metody diagnostyki i leczenia, jak również o dopuszczeniu osób trzecich do informacji o pacjencie i do sfery jego prywatności. Głównym przejawem poszanowania autonomii pacjenta niewątpliwie jest obowiązek uzyskania zgody na interwencję medyczną po stronie personelu medycznego i odpowiadające mu prawo pacjenta do wyrażenia tej zgody. Prawo do podejmowania decyzji dotyczących własnego zdrowia jest jednym z ważniejszych praw pacjenta. Dlatego też dokonanie zabiegu leczniczego bez jego zgody jest przestępstwem, przewidzianym w art. 192 ustawy z dnia 6 czerwca 1997 r. - Kodeks karny ${ }^{1}$. Co więcej, zdaniem Sądu Apelacyjnego w Warszawie, zabieg przeprowadzony bez zgody pacjenta, jest czynnością bezprawną, nawet wówczas, gdy wykonany jest zgodnie z zasadami wiedzy².

* Dr, Uniwersytet Marii Curie-Skłodowskiej w Lublinie; e-mail: agnieszka.woloszyncichocka@poczta.umcs.lublin.pl.

1 Ustawa z dnia 6 czerwca 1997 r. - Kodeks karny, tekst jednolity: Dz. U. z 2018 r. poz. 1600 z późn. zm.

2 Wyrok Sądu Apelacyjnego w Warszawie z dnia 31 marca 2006 r., I ACa 973/05, LEX nr 252827; zob. również aprobującą glosę M. Nesterowicza, tenże, Wyrok Sądu Apela- 
Przedmiotem niniejszego artykułu jest analiza obowiązujących rozwiązań prawnych w zakresie reguł wyrażania zgody na udzielenie świadczenia zdrowotnego przez pacjenta będącego dzieckiem. Wskazana problematyka nie ma wyłącznie teoretycznego znaczenia. Mnogość regulacji prawnych, ich kazuistyka i nierzadko niespójność mogą bowiem rodzić szereg trudności $\mathrm{w}$ praktyce ich stosowania. Wiele wątpliwości budzi zwłaszcza granica wieku, od której polski prawodawca dopuszcza możliwość samodzielnego decydowania o poddaniu się interwencji medycznej. Autorka postawiła sobie zatem za cel wskazanie najważniejszych aktów normatywnych, regulujących problematykę wyrażania zgody na udzielenie świadczenia zdrowotnego i wspomnianą granicę wieku, a także przeanalizowanie zalet i wad rozwiązań przyjętych przez ustawodawcę oraz sformułowanie wniosków de lege ferenda. Rozważania prowadzone są z szerokim uwzględnieniem orzecznictwa sądowego, jak również poglądów przedstawicieli doktryny.

\section{Istota zgody na udzielenie świadczenia zdrowotnego}

W literaturze przedmiotu zgoda pacjenta definiowana jest jako:

swobodnie podjęty i wyrażony według reguł znaczeniowych dostępnych dla innych uczestników procesu medycznego akt woli pacjenta lub jego przedstawiciela ustawowego, podjęty na podstawie przystępnie udzielonej, rzetelnej informacji co do wszelkich stadiów postępowania medycznego ${ }^{3}$.

Z kolei ustawodawca zdefiniował zgodę jedynie $\mathrm{w}$ stosunku do świadczeń z zakresu ochrony zdrowia psychicznego. Zgodnie z art. 3 pkt 4 ustawy z dnia 19 sierpnia 1994 r. o ochronie zdrowia psychicznego ${ }^{4}$ oznacza ona:

swobodnie wyrażoną zgodę osoby z zaburzeniami psychicznymi, która - niezależnie od stanu jej zdrowia psychicznego - jest rzeczywiście zdolna do zro-

cyjnego w Warszawie z dnia 31 marca 2006 r., I A Ca 973/05, LEX nr 252827, „Prawo i Medycyna" 2010, nr 2, s. 125-134.

3 M. Świderska, Zgoda Pacjenta na zabieg medyczny, Toruń 2007, s. 19.

4 Ustawa z dnia 19 sierpnia 1994 r. o ochronie zdrowia psychicznego, tekst jednolity: Dz. U. z 2018 r. poz. 1878 z późn. zm. 
zumienia przekazywanej $\mathrm{w}$ dostępny sposób informacji o celu przyjęcia do szpitala psychiatrycznego, jej stanie zdrowia, proponowanych czynnościach diagnostycznych i leczniczych oraz o dających się przewidzieć skutkach tych działań lub ich zaniechania.

Skuteczność tak rozumianej zgody zależy od zaistnienia przesłanek, takich jak m.in.: brak wad oświadczenia woli, zachowanie wymaganej prawem formy, brak sprzeczności przedmiotu zgody z prawem lub zasadami współżycia społecznego, a także wyrażenie zgody przez uprawniony do tego podmiot ${ }^{5}$. Ważne jest również to, aby zgodę poprzedziła rzetelna, wyczerpująca informacja medyczna, przedstawiona w sposób zrozumiały, przystępny dla pacjenta. Nie ulega wątpliwości, że tylko uprzednie poinformowanie pacjenta o diagnozie, rokowaniach, możliwych i proponowanych metodach leczenia i ewentualnym ryzyku ${ }^{6}$ powinno być podstawą do podjęcia decyzji o ewentualnej interwencji medycznej. Świadomość podejmowanych decyzji jest obecnie najczęściej akcentowanym elementem skutecznej zgody pacjenta, dlatego też obowiązującym standardem podczas udzielania świadczeń zdrowotnych na świecie jest zasada informed consent, czyli zgody uświadomionej, objaśnionej, poinformowanej ${ }^{7}$. Zgodnie ze stanowiskiem Sądu Najwyższego (SN) „sama aprobata pacjenta dokonania zabiegu, uzyskana w sytuacji braku uprzedniego udzielenia mu przystępnej informacji, nie może być traktowana jako zgoda"8, "a bezskuteczność zgody spowodowana nieudzieleniem właściwej informacji przesądza o bezprawności działania lekarza" 9 .

5 Zob. D. Karkowska, Ustawa o prawach pacjenta i Rzeczniku Praw Pacjenta. Komentarz, Warszawa 2012, s. 229; U. Drozdowska, W. Wojtal, Zgoda i informowanie pacjenta, Warszawa 2010, s. 17; M. Filar, Postępowanie lecznicze (świadczenie zdrowotne) w stosunku do pacjenta niezdolnego do wyrażenia zgody, "Prawo i Medycyna” 2003, nr 13, s. 41; M. Malczewska, Komentarz do art. 32 ustawy o zawodach lekarza i lekarza dentysty, [w:] E. Zielińska (red.), Ustawa o zawodach lekarza i lekarza dentysty. Komentarz, Warszawa 2014, s. 602; S. Rutkowski, Zgoda na zabieg leczniczy w ujęciu art. 192 k.k., „Prokuratura i Prawo” 2000, nr 2, s. 20.

6 Zob. S. Niemczyk, A. Łazarska, Medyczno-prawne rozważania o konkretyzacji przedmiotu zgody pacjenta, „Prawo i Medycyna” 2008, nr 3, s. 65 i nast.

7 Zob. M. Świderska, Zgoda Pacjenta..., s. 17.

8 Wyrok Sądu Najwyższego z dnia 16 maja 2012 r., III CSK 227/11, OSNC-ZD z 2013 r., nr 1, poz. 23; zob. M. Świderska, Glosa do wyroku Sądu Najwyższego z dnia 16 maja 2012, sygn. III CSK 227/11, LEX nr 1211885, „Prawo i Medycyna” 2012, nr 3/4, s. 246-252.

9 Wyrok Sądu Najwyższego z dnia 18 stycznia 2013 r., IV CSK 431/12, LEX nr 1275006. 
Istotne znaczenie ma również przedmiot zgody, a ten z kolei powinien być odpowiednio sprecyzowany. Pacjent wyraża zatem zgodę na określone świadczenie zdrowotne, a nie ogólnie na leczenie. Pozwala tym samym na naruszenie integralności cielesnej tylko w ustalonym zakresie. Lekarz powinien więc uzyskać zgodę pacjenta na wszelkie zabiegi, nie tylko terapeutyczne, ale też poprzedzające je zabiegi diagnostyczne, które często także mają charakter inwazyjny. Jak słusznie twierdzi M. Nesterowicz, „lekarz powinien działać w granicach zgody pacjenta, wszelkie carte blanche na leczenie należy uznać za nieważne"10. W wyjątkowych sytuacjach lekarz może podjąć działanie bez zgody pacjenta, ale są to przypadki wyraźnie uregulowane przepisami prawa.

Wyrażając zgodę na udzielenie świadczenia zdrowotnego, pacjent akceptuje ryzyko z nim związane i przejmuje je na siebie. Nie zwalnia to jednak lekarza z obowiązku zachowania należytej staranności, ponieważ jak stwierdził SN:

ryzyko, jakie bierze na siebie pacjent, wyrażając zgodę na zabieg operacyjny, obejmuje tylko zwykłe powikłania pooperacyjne, nie można natomiast uznać, by ryzykiem pacjenta były objęte komplikacje powstałe wskutek pomyłki, nieuwagi lub niezręczności lekarza, zwłaszcza - uszkodzenia innego organu, także w sposób przypadkowy i niezamierzony ${ }^{11}$.

Warto jednak wspomnieć, że w doktrynie pojawiają się wątpliwości, co do przejęcia przez pacjenta wraz ze zgodą ryzyka interwencji medycznej. Zwraca się bowiem uwagę, że lekarze, chroniąc własną pozycję oraz interesy podmiotu leczniczego, mogą wykorzystywać instytucję zgody do przerzucenia na pacjenta odpowiedzialności za wybór metody leczenia oraz jego skutki ${ }^{12}$. Oczywiście takich wypadków nie można wykluczyć, jednakże wydaje się, że korzyści z przestrzegania obowiązku uzyskania zgody pacjenta na udzielenie świadczenia zdrowotnego są większe aniżeli wskazane powyżej zastrzeżenia. Wolność pacjenta i możliwość samodzielnego zadecydowania o poddaniu się leczeniu ma w tym przypadku znaczenie priorytetowe.

10 M. Nesterowicz, Prawo medyczne. Glosy i komentarze do orzeczeń sądowych, Warszawa 2012, s. 113.

11 Wyrok Sądu Najwyższego z dnia 18 stycznia 2013 r., IV CSK 431/12, LEX nr 1275006.

12 Zob. W. Bołoz, Geneza, ewolucja i etyczne uzasadnienie zasady "świadomej zgody", [w:] W. Bołoz, R. Krajewski (red.), Realizacja zasady informed consent w kontekście relacji lekarz pacjent. Wyzwania i bariery rozwojowe w Polsce, Warszawa 2012, s. 40. 
Zasady wyrażania zgody na udzielenie świadczenia zdrowotnego, jej formę oraz podmioty do tego uprawnione polski ustawodawca uregulował głównie w dwóch ustawach - w ustawie z dnia 5 grudnia 1996 r. o zawodach lekarza i lekarza dentysty ${ }^{13}$ oraz w ustawie $\mathrm{z}$ dnia 6 listopada 2008 r. o prawach pacjenta i Rzeczniku Praw Pacjenta ${ }^{14}$. Ustawy te należy przy tym traktować jako lex generalis $\mathrm{w}$ stosunku do szeregu regulacji prawnych, które przewidują odmienne reguły wyrażania zgody na interwencje medyczne, podyktowane specyfiką tych interwencji. Wśród ustaw, które można uznać za lex specialis w stosunku do u.z.l. i u.p.p. w zakresie wyrażania zgody na udzielenie świadczenia zdrowotnego, warto wymienić m.in. ustawę z dnia 1 lipca 2005 r. o pobieraniu, przechowywaniu i przeszczepianiu komórek, tkanek i narządów ${ }^{15}$, ustawę z dnia 22 sierpnia 1997 r. o publicznej służbie krwi ${ }^{16}$ czy też ustawę z dnia 6 września 2001 r. - Prawo farmaceutyczne ${ }^{17}$.

\section{Zasady wyrażania przez dziecko zgody na udzielenie świadczenia zdrowotnego na gruncie ustawy z dnia 5 grudnia $1996 \mathrm{r}$. o zawodach lekarza i lekarza dentysty oraz ustawy z dnia 6 listopada 2008 r. o prawach pacjenta i Rzeczniku Praw Pacjenta}

Analizując okoliczności, które mają istotny wpływ na skuteczność zgody na udzielenie świadczenia zdrowotnego, należy ustalić czy jest ona wyrażana przez podmiot do tego uprawniony. Na zdolność do wyrażenia zgody mają wpływ: wiek pacjenta, jego ubezwłasnowolnienie oraz faktyczna zdolność do podjęcia takiej decyzji. Z uwagi na przedmiot publikacji, uwaga zostanie skupiona jedynie na pierwszej okoliczności, która

13 Ustawa z dnia 5 grudnia 1996 r. o zawodach lekarza i lekarza dentysty, tekst jednolity: Dz. U. z 2019 r. poz. 537 z późn. zm. (dalej: u.z.l.).

14 Ustawa z dnia 6 listopada 2008 r. o prawach pacjenta i Rzeczniku Praw Pacjenta, tekst jednolity: Dz. U. z 2019 r. poz. 1127 z późn. zm. (dalej: u.p.p.).

15 Ustawa z dnia 1 lipca 2005 r. o pobieraniu, przechowywaniu i przeszczepianiu komórek, tkanek i narządów, tekst jednolity: Dz. U. z 2019 r. poz. 1405.

16 Ustawa z dnia 22 sierpnia 1997 r. o publicznej służbie krwi, tekst jednolity: Dz. U. z 2019 r. poz. 1222.

17 Ustawa z dnia 6 września 2001 r. - Prawo farmaceutyczne, tekst jednolity: Dz. U. z 2019 r. poz. 499 z późn. zm. 
niewątpliwie może ograniczać, a nawet uniemożliwiać skuteczne wyrażenie zgody na działanie medyczne. Warto jednak w pierwszej kolejności ustalić, kim w obowiązującym stanie prawnym jest dziecko, bowiem ani u.p.p. ani u.z.l. nie posługują się takim pojęciem.

Znaczenie pojęcia „dziecko" niejednokrotnie było przedmiotem rozważań w doktrynie ${ }^{18}$. Definiując je, najczęściej podkreśla się brak dojrzałości psychicznej i płciowej. Jak pisze B. Olszewski, dziecko „kojarzone jest z pewnym okresem życia człowieka oraz ze stanem niedojrzałości fizycznej, psychicznej i - z uwagi na swoją niedojrzałość fizyczną oraz umysłową - wymaga szczególnej opieki i troski, w tym właściwej ochrony prawnej zarówno przed, jak i po urodzeniu"19.

Zgodnie z art. 1 Konwencji o prawach dziecka ${ }^{20}{ }_{\text {„w }}$ rozumieniu niniejszej konwencji «dziecko» oznacza każdą istotę ludzką w wieku poniżej osiemnastu lat, chyba że zgodnie z prawem odnoszącym się do dziecka uzyska ono wcześniej pełnoletność". Tymczasem polski prawodawca nie zawsze posługuje się pojęciem „dziecka”. Pojawia się ono m.in. w Konstytucji Rzeczypospolitej Polskiej z dnia 2 kwietnia 1997 r. ${ }^{21}$ (np. w art. 48 ust. 1, art. 53 ust. 3 czy art. 68 ust. 3), w ustawie z dnia 25 lutego 1964 r. - Kodeks rodzinny i opiekuńczy ${ }^{22}$, a także w ustawie z dnia 6 stycznia 2000 r. o Rzeczniku Praw Dziecka ${ }^{23}$. Zgodnie z art. 2 ust. 1 ostatniej ze wskazanych ustaw dzieckiem jest „każda istota ludzka od poczęcia do osiągnięcia pełnoletności". Zasady uzyskiwania pełnoletności regulują natomiast przepisy ustawy z dnia 23 kwietnia 1964 r. - Kodeks cywilny ${ }^{24}$, w którym to ustawodawca posługuje się również określeniem „małolet-

18 Zob. M. Dercz, H. Izdebski, T. Rek, Dziecko - pacjent i świadczeniobiorca, Warszawa 2015; M.J. Zajączkowska, Prawa dziecka, [w:] L. Koba, W. Wacławczyk (red.), Prawa człowieka. Wybrane zagadnienia i problemy, Warszawa 2009, s. 369-383.

19 B. Olszewski, Uniwersalna definicja dziecka?, „Przegląd Prawa i Administracji” 2011, nr 85, s. 214.

20 Konwencja o prawach dziecka, przyjęta przez Zgromadzenie Ogólne Narodów Zjednoczonych dnia 20 listopada 1989 r., Dz. U. z 1991 r. Nr 120, poz. 526.

${ }^{21}$ Konstytucja Rzeczypospolitej Polskiej z dnia 2 kwietnia 1997 r., Dz. U. z 1997 r. Nr 78, poz. 483 z późn. zm.

22 Ustawa z dnia 25 lutego 1964 r. - Kodeks rodzinny i opiekuńczy, tekst jednolity: Dz. U. z 2017 r. poz. 682 z późn. zm.

23 Ustawa z dnia 6 stycznia 2000 r. o Rzeczniku Praw Dziecka, tekst jednolity: Dz. U. z 2017 r. poz. 922 z późn. zm.

24 Ustawa z dnia 23 kwietnia 1964 r. - Kodeks cywilny, tekst jednolity: Dz. U. z 2019 r. poz. 1145 (dalej: k.c.). Zgodnie z art. 10 § 1 k.c. pełnoletnim jest ten, kto ukończył osiem- 
ni”. Termin "małoletni”, występujący w wielu aktach normatywnych, w tym wspomnianych powyżej u.z.l. i u.p.p., nie jest jedynym, który występuje obok pojęcia „dziecka”. Ustawodawca posługuje się również słowem „nieletni” (np. w Kodeksie karnym) czy „młodociany” (np. w ustawie z dnia 6 czerwca 1997 r. - Kodeks karny wykonawczy 25). Mnogość pojęć oraz brak uniwersalnej definicji niewątpliwie utrudnia ustalenie, kim dokładnie jest dziecko. Nawiązując jednak do definicji dziecka z ustawy o Rzeczniku Praw Dziecka, a także do reguł ustalania pełnoletności przewidzianych w art. 10 k.c., można stwierdzić, że dzieckiem jest każda istota ludzka od poczęcia do ukończenia osiemnastego roku życia, ewentualnie do zawarcia małżeństwa, jeśli nastąpiło ono przed ukończeniem osiemnastego roku życia.

Wskazane powyżej u.z.l. i u.p.p., jako najważniejsze podstawy prawne w zakresie zgody na udzielenie świadczenia zdrowotnego, posługują się pojęciem pacjenta małoletniego. Różnicują jednak jego sytuację prawną w zależności od tego, czy ukończył on 16 lat, czy nie. Zgodnie z art. 17 ust. 1 u.p.p. pacjent, w tym małoletni, który ukończył 16 lat, ma prawo do wyrażenia zgody na przeprowadzenie badania lub udzielenie innych świadczeń zdrowotnych. Również art. 32 ust. 5 u.z.l. przewiduje, że jeżeli pacjent ukończył 16 lat, wymagana jest także jego zgoda. O ile jednak pacjent pełnoletni, posiadający pełną zdolność do czynności prawnych i faktycznie zdolny do świadomego wyrażenia zgody decyduje samodzielnie o poddaniu się leczeniu, to pacjent małoletni, który ukończył 16 lat, decyduje wspólnie z przedstawicielem ustawowym (tzw. zgoda równoległa). Z kolei za pacjenta, który nie ukończył 16 lat zgodę wyraża wyłącznie przedstawiciel ustawowy (tzw. zgoda zastępcza, art. 17 ust. 2 u.p.p., art. 32 ust. 2 u.z.l.).

W literaturze przedmiotu nie ma zgodności co do tego, czy ustawodawca słusznie przyjął granicę wieku na poziomie 16 roku życia, jako tę, od której pacjent jest w stanie świadomie decydować o poddaniu się interwencji medycznej. Według M. Malczewskiej osoba, która nie ukończyła 16 lat, też może być zdolna do świadomej i racjonalnej oceny swojego stanu zdrowia i mogłaby z rozeznaniem podjąć decyzję co do proponowanych

naście lat, natomiast art. 10 § 2 k.c. przesądza, że przez zawarcie małżeństwa małoletni uzyskuje pełnoletność i nie traci jej w razie unieważnienia małżeństwa.

25 Ustawa z dnia 6 czerwca 1997 r. - Kodeks karny wykonawczy, tekst jednolity: Dz. U. z 2019 r. poz. 676 z późn. zm. 
metod diagnozowania i leczenia ${ }^{26}$. Podobnie twierdzi R. Kędziora, która proponuje obniżenie granicy wieku, od którego małoletni pacjent mógłby współdecydować o udzielanych mu świadczeniach, do 14 roku ży$\mathrm{cia}^{27}$ oraz A. Michałek-Janiczek, która postuluje, by była to granica 13 roku życia ${ }^{28}$. Z kolei M. Świderska opowiada się nawet za całkowitym zniesieniem granicy wieku, od której istniałby obowiązek uzyskania zgody małoletniego pacjenta. Zdaniem autorki prawo powinno określać jedynie ogólne wskazówki, umożliwiające rozważanie każdorazowo, czy pacjent jest dostatecznie świadomy do wyrażenia zgody ${ }^{29}$.

Analizując przedstawione stanowiska, należy zgodzić się z twierdzeniem, że sztywno określona granica wieku, przesądzająca o możliwości samodzielnego wyrażania zgody na udzielenie świadczenia zdrowotnego, nie zawsze odpowiada stopniowi rozwoju intelektualnego i emocjonalnego pacjenta. Szukając optymalnego rozwiązania, trudno jednak zaakceptować obniżenie granicy wieku do 15 lat czy do 14 lat. Wydaje się, że zaproponowane rozwiązania nie zakończyłyby dyskusji, ponieważ z pewnością znalazłyby się osoby uważające, że jest to zbyt niski lub wciąż zbyt wysoki margines. Propozycja całkowitej rezygnacji z granicy wieku na rzecz indywidualnej oceny stopnia rozeznania małoletniego pacjenta również budzi obawy. Byłoby to niewątpliwie utrudnieniem dla lekarzy, którzy musieliby w każdym przypadku oceniać, czy małoletni pacjent mógłby wyrazić świadomą zgodę na udzielenie świadczenia zdrowotnego. Z drugiej strony można byłoby też zarzucić im brak obiektywizmu i uznaniowość decyzji.

W kontekście rozważań na temat granicy wieku, od którego pacjentowi małoletniemu przysługiwałoby prawo do wyrażenia zgody na działanie medyczne, warto wspomnieć o wyroku Trybunału Konstytucyjnego (TK) z dnia 11 października 2011 r. (sygn. K 16/10) 30. Inicjatorem postępowania przed TK był Rzecznik Praw Obywatelskich, który podobnie jak wielu przedstawicieli doktryny, negował przepisy ustaw regulujących udzielanie świadczeń zdrowotnych, które przyznają małoletnim pacjentom pra-

26 Zob. M. Malczewska, Komentarz do art. 32 ustawy o zawodach lekarza..., s. 607.

27 Zob. R. Kędziora, Problematyka zgody pacjenta w świetle polskiego ustawodawstwa medycznego, „Prokuratura i Prawo” 2003, nr 7/8, s. 50.

28 Zob. A. Michałek-Janiczek, Autonomia małoletniego w zakresie leczenia, „Państwo i Prawo" 2009, z. 10, s. 65.

29 Zob. M. Świderska, Zgoda Pacjenta..., s. 63.

30 Wyrok Trybunału Konstytucyjnego z dnia 11 października 2011 r., K 16/10, OTK ZU 2011, nr 8A, poz. 80. 
wo do współdecydowania o procesie leczenia po ukończeniu przez nich 16 roku życia. Wnioskodawca negatywnie ocenił przyjętą $\mathrm{w}$ ustawach dolną granicę wieku - jako zbyt wysoką, a także zwrócił uwagę na arbitralność i automatyzm w działaniu, ignorujące indywidualną zdolność konkretnego małoletniego pacjenta do świadomego i odpowiedzialnego stanowienia o sobie. Trybunał Konstytucyjny uznał jednak, że zakwestionowane przepisy nie naruszają autonomii małoletnich pacjentów. Zwrócił jednak uwagę na istnienie wadliwości przepisów prawa medycznego, regulujących przesłanki odbierania przez lekarzy zgody na świadczenia zdrowotne, np. na rozbudowaną kazuistykę. Odpowiadając na propozycję rezygnacji z kryterium wieku na rzecz stopnia rozeznania pacjenta, TK stwierdził:

uzależnienie wymagania osobistej zgody małoletniego pacjenta od pozio$\mathrm{mu}$ jego rozwoju wiązałoby się z koniecznością stworzenia instytucjonalnej kontroli tego poziomu w każdym indywidualnym wypadku. Oznaczałoby to z kolei konieczność zapewnienia profesjonalnej służby w każdym niemal zakładzie opieki zdrowotnej. Opóźniałoby także udzielenie pomocy lekarskiej ${ }^{31}$.

Zagadnienie prawa pacjenta - dziecka do wyrażenia zgody na udzielenie świadczenia zdrowotnego nie sprowadza się jednak wyłącznie do ustalenia granicy wieku, od którego prawo to przysługuje, ale jest o wiele bardziej złożone. Zarówno u.z.l. jak i u.p.p. regulują również sytuacje, gdy nie ma kontaktu z przedstawicielem ustawowym pacjenta, gdy zgodę wyraża opiekun faktyczny, a także przypadki konfliktów pomiędzy pacjentem i jego przedstawicielem ustawowym. Zgodnie z art. 17 ust. 2 zd. 2 u.p.p. oraz art. 32 ust. 3 u.z.l. w przypadku braku przedstawiciela ustawowego prawo to, w odniesieniu do badania, może wykonać opiekun faktyczny. Natomiast sytuację, w której pacjent nie ma przedstawiciela ustawowego lub porozumienie $\mathrm{z}$ nim nie jest możliwe, reguluje wyłącznie u.z.l. Zgodnie z art. 32 ust. 2 u.z.l. wówczas wymagane jest zezwolenie sądu opiekuńczego.

Pacjent małoletni, który ukończył 16 lat, nie zawsze musi zgadzać się z decydującym wspólnie z nim przedstawicielem ustawowym. Dlatego też ustawodawca przyznał mu prawo sprzeciwu wobec czynności medycznych. Artykuł 17 ust. 3 u.p.p. przewiduje konieczność uzyskania zezwolenia sądu opiekuńczego w przypadku zgody przedstawiciela ustawowego i sprzeciwu pacjenta małoletniego, który ukończył 16 lat.

31 Tamże. 
Rozstrzygnięcie konfliktu przez sąd wydaje się słusznym rozwiązaniem, ponieważ umożliwia weryfikację decyzji podejmowanych często pod wpływem emocji i przez to nie zamyka drogi do udzielenia świadczenia zdrowotnego. W literaturze przedmiotu można jednak spotkać odmienne oceny tej regulacji. Zdaniem D. Karkowskiej "przełamanie sprzeciwu”, bo tak autorka określa zastąpienie decyzji podmiotu sprzeciwiającego się interwencji medycznej zezwoleniem sądu, czyni autonomię osób o ograniczonej możliwości decydowania fikcją ${ }^{32}$.

Jeszcze więcej wątpliwości budzi rozwiązanie przyjęte przez ustawodawcę $w$ u.z.l. Zgodnie $z$ art. 32 ust. 6 u.z.l. przełamanie sprzeciwu pacjenta zezwoleniem sądu będzie możliwe nie tylko wówczas, gdy przedstawiciel ustawowy pacjenta zgadza się na udzielenie świadczenia zdrowotnego, ale nawet wtedy, gdy tej zgody nie wyraża. Oznacza to, że sąd może zezwolić na udzielenie świadczenia zdrowotnego nawet wtedy, gdy nie zgadza się na nie ani małoletni pacjent, ani jego przedstawiciel ustawowy. Działanie wbrew ich woli niewątpliwie jest ograniczeniem autonomii decyzyjnej, jednakże w literaturze można spotkać poglądy aprobujące takie rozwiązanie. Według A. Dudzińskiej przedstawiciel ustawowy nie zawsze musi działać w interesie pacjenta, ten zaś może podejmować decyzję pod wpływem presji otoczenia ${ }^{33}$. W takiej sytuacji możliwość rozstrzygnięcia tej kwestii przez sąd wydaje się słusznym rozwiązaniem, gdyż stwarza szansę na ratowanie zdrowia i życia pacjenta, gdy być może oceniając obiektywnie, świadczenie zdrowotne powinno zostać mu udzielone.

W kontekście rozważań na temat prawa pacjenta - dziecka do wyrażenia zgody na udzielenie świadczenia zdrowotnego warto również poddać analizie przypadki zgody na leczenie stwarzające podwyższone ryzyko dla pacjenta. Zgodnie z art. 18 ust. 1 u.p.p. oraz 34 ust. 1 u.z.l. zgoda taka musi być wyrażona w formie pisemnej. Podobnie jak w przypadku zgody na inne interwencje medyczne, za pacjenta małoletniego decyduje jego przedstawiciel ustawowy, a gdy pacjent ukończył 16 lat, niezbędna jest również jego pisemna zgoda. Należy przy tym zwrócić uwagę, na sytuację uregulowaną przez ustawodawcę $\mathrm{w}$ art. 34 ust. 6 u.z.l. Zgodnie z jego treścią, gdy przedstawiciel ustawowy pacjenta małoletniego nie zgadza się na wykonanie przez lekarza zabiegu operacyjnego albo zastosowanie metody leczenia lub diagnostyki stwarzającej podwyższone ryzyko, ale nie-

32 Zob. D. Karkowska, Ustawa o prawach pacjenta..., s. 240.

33 Zob. A. Dudzińska, Zgoda na działanie medyczne, „Państwo i Prawo” 2009, z. 11, s. 72. 
zbędnych dla usunięcia niebezpieczeństwa utraty przez pacjenta życia lub ciężkiego uszkodzenia ciała bądź ciężkiego rozstroju zdrowia, lekarz może wykonać takie czynności po uzyskaniu zgody sądu opiekuńczego. W tym przypadku zastanawiające jest to, że ustawodawca pominął zupełnie zdanie pacjenta małoletniego, który ukończył 16 lat. Artykuł 34 ust. 6 u.z.l. stanowi podstawę do rozstrzygnięcia sporu pomiędzy lekarzem a przedstawicielem ustawowym, niezależnie od woli mogącego już w pewnym stopniu decydować pacjenta. Pozostaje więc wierzyć, że stanowisko tych pacjentów uwzględni sąd opiekuńczy, podejmując rozstrzygnięcie w sprawie ewentualnej zgody na leczenie stwarzające podwyższone ryzyko.

Niezależnie od powyżej przedstawionych przypadków, należy dodać, że zarówno u.p.p., jak i u.z.l. przyznaje lekarzowi prawo udzielenia świadczenia zdrowotnego bez zgody pacjenta czy też jego przedstawiciela ustawowego lub opiekuna faktycznego, gdy zgody tej nie można uzyskać, a pacjent wymaga niezwłocznej pomocy lekarskiej (art. 19 u.p.p. i art. 33 u.z.l.). Takie rozwiązanie należy uznać za właściwe, ponieważ w konflikcie pomiędzy życiem i zdrowiem człowieka oraz jego autonomią, pozwala na ratowanie wartości cenniejszej. Warto przy tym podkreślić, że działanie lekarza w analizowanym przypadku wcale nie musi oznaczać działania wbrew woli pacjenta czy jego przedstawiciela ustawowego. Niewykluczone, że ten zgodziłby się na udzielenie świadczenia zdrowotnego, gdyby było to możliwe. Podjęcie działania w tym przypadku opiera się zatem na zgodzie domniemanej ${ }^{34}$. Jednakże ze względu na to, że podejmowana na podstawie art. 33 u.z.l. interwencja medyczna jest ograniczeniem autonomii pacjenta, należy ją traktować jako wyjątek od zasady obowiązku uzyskania zgody na udzielenie świadczenia zdrowotnego i w związku z tym powinna ograniczać się wyłącznie do zabiegów niezbędnych w danej sytuacji.

\section{Szczególne przypadki zgody na udzielenie świadczenia zdrowotnego wyrażanej przez dziecko}

Wskazane powyżej przepisy u.p.p. i u.z.l. stanowią lex generalis w zakresie zgody na działania medyczne. Warto jednak zwrócić uwagę na odmienne uregulowania zgody pacjenta - dziecka na udzielenie świadcze-

34 Zob. M. Świderska, Zgoda Pacjenta..., s. 178 i nast. 
nia zdrowotnego. Pozostając przy u.z.l., należy poddać analizie zasady przeprowadzania eksperymentów medycznych z udziałem małoletnich. Ustawa ta przewiduje dwa rodzaje eksperymentów medycznych. Zgodnie $\mathrm{z}$ art. 21 ust. 2 u.z.l. pierwszy z nich - eksperyment leczniczy - polega na wprowadzeniu przez lekarza nowych lub tylko częściowo wypróbowanych metod diagnostycznych, leczniczych lub profilaktycznych w celu osiągnięcia bezpośredniej korzyści dla zdrowia osoby leczonej i można go przeprowadzić wyłącznie wtedy, gdy dotychczas stosowane metody medyczne nie są skuteczne lub jeżeli ich skuteczność nie jest wystarczająca. Z kolei eksperyment badawczy - zdefiniowany przez ustawodawce w art. 21 ust. 3 u.z.l. - ma na celu rozszerzenie wiedzy medycznej i może być przeprowadzany zarówno na osobach chorych, jak i zdrowych, jednakże tylko wówczas, gdy uczestnictwo $\mathrm{w}$ nim nie jest związane $\mathrm{z}$ ryzykiem albo ryzyko jest niewielkie i nie pozostaje $\mathrm{w}$ dysproporcji do możliwych pozytywnych rezultatów takiego eksperymentu. Zasadą jest, że eksperyment medyczny może być przeprowadzony po wyrażeniu przez uczestnika pisemnej zgody. Natomiast gdy pacjentem jest małoletni, to, zgodnie z art. 25 ust. 2 u.z.l., niezbędna jest pisemna zgoda jego przedstawiciela ustawowego, a jeśli małoletni ukończył 16 lat lub nie ukończył 16 lat $\mathrm{i}$ jest $\mathrm{w}$ stanie $\mathrm{z}$ rozeznaniem wypowiedzieć opinię $\mathrm{w}$ sprawie swego uczestnictwa w eksperymencie, konieczna jest także jego pisemna zgoda. Wskazane rozwiązanie różni się od reguł ogólnych wyrażania przez małoletniego zgody na interwencję medyczną. W przypadku eksperymentów medycznych ustawodawca przy ustalaniu granicy, od której małoletni pacjent ma prawo do wyrażenia zgody, oprócz kryterium wieku uwzględnił również stopień jego rozeznania. Rozwiązanie takie zasługuje na aprobatę, ponieważ jest bardziej elastyczne i umożliwia indywidualne podejście do pacjenta. Oczywiście w praktyce mogą pojawić się wątpliwości, jak dokładnie ustalać stopień rozeznania potencjalnego małoletniego uczestnika eksperymentu, jednakże jak twierdzą A. Gałęska-Śliwka i K. Śliwka, w takich sytuacjach na badaczu spoczywa ciężar każdorazowej analizy z zachowaniem należytej staranności celem ustalenia stopnia rozeznania decydującego o możliwości wyrażania zgody ${ }^{35}$. Dodatkowo warto zwrócić uwagę, że udział małoletniego w eksperymencie badawczym jest dopuszczalny tylko wtedy, gdy spodziewane korzyści mają bezpośrednie

35 Zob. A. Gałęska-Śliwka, K. Śliwka, Zgoda małoletniego na udział w eksperymencie medycznym, „Archiwum Medycyny Sądowej i Kryminologii” 2008, t. 58, nr 4, s. 195. 
znaczenie dla jego zdrowia, a ryzyko jest niewielkie i nie pozostaje w dysproporcji do możliwych pozytywnych rezultatów. Natomiast gdy przeprowadzenie eksperymentu badawczego o porównywalnej efektywności jest możliwe z udziałem osoby o pełnej zdolności do czynności prawnych, wówczas udział małoletniego jest niedopuszczalny, o czym przesądza art. 25 ust. 3 u.z.l. Słusznie pisze J. Haberko, że „ze względu na wartość, którą ustawodawca zdaje się chronić, przeprowadzanie eksperymentu badawczego powinno uwzględniać dobro i interes zdrowotny poddawanego eksperymentowi małoletniego" ${ }^{36}$.

Pozostając w obszarze eksperymentów medycznych, należy wspomnieć o zasadach wyrażania zgody na udział w badaniach klinicznych produktów leczniczych, te zaś ustawodawca unormował w Prawie farmaceutycznym. Zgodnie $\mathrm{z}$ art. 37a ust. 2 wspomnianej ustawy badanie kliniczne produktu leczniczego jest eksperymentem medycznym. Z art. 37f Prawa farmaceutycznego wynika, że zgoda na udział w badaniu powinna mieć formę pisemną (a gdy nie jest to możliwe - ustną wyrażoną w obecności dwóch świadków) i zawierać datę i podpis osoby uprawnionej do złożenia oświadczenia, a także wzmiankę, iż została wyrażona po otrzymaniu odpowiednich informacji dotyczących istoty, znaczenia, skutków i ryzyka związanego $\mathrm{z}$ badaniem klinicznym. Ustawodawca nie sprecyzował przy tym, kto posiada zdolność do wyrażenia zgody na udział w badaniu, ograniczając się jedynie do stwierdzenia, że oświadczenie składane jest dobrowolnie przez osobę zdolną do jego złożenia, a w przypadku osoby niezdolnej do złożenia takiego oświadczenia - przez jej przedstawiciela ustawowego ${ }^{37}$.

Kolejnym aktem normatywnym istotnym w kontekście rozważań na temat prawa do wyrażenia zgody na czynności medyczne jest ustawa o pobieraniu, przechowywaniu i przeszczepianiu komórek, tkanek i narządów, a w szczególności uregulowane w niej zasady pobierania komórek, tkanek i narządów od dawców żywych. Zgodnie z art. 12 ust. 1 pkt 7 wspomnianej ustawy kandydat na dawcę musi mieć pełną zdolność do czynności prawnych, a swoją zgodę musi wyrazić w formie pisemnej.

${ }^{36}$ J. Haberko, Małoletni pacjent jako podmiot interesu prawnie chronionego w kontekście wybranych aspektów stosowania nowoczesnych technologii medycznych, [w:] O. Nawrot, A. Wnukiewicz-Kozłowska (red.), Temida w dobie rewolucji biotechnologicznej - wybrane problemy bioprawa, Gdańsk 2015, s. 45.

37 Szerzej na temat zgody małoletniego na udział w badaniach klinicznych produktów leczniczych, zob. M. Czarkowski, Zgoda na udział w badaniach klinicznych osób niezdolnych do jej wyrażenia, „Prawo i Medycyna” 2014, nr 3/4, s. 91-106. 
Odmiennie kształtują się jednak zasady przeszczepu szpiku i komórek krwiotwórczych. Na podstawie art. 12 ust. 2 ustawy małoletni może być dawcą na rzecz rodzeństwa, jeżeli nie spowoduje to dającego się przewidzieć upośledzenia sprawności organizmu dawcy i wyłącznie w sytuacji, gdy zachodzi bezpośrednie niebezpieczeństwo utraty życia, a niebezpieczeństwa takiego nie można uniknąć w inny sposób niż przez dokonanie przeszczepu szpiku lub komórek krwiotwórczych krwi obwodowej. Natomiast art. 12 ust. 3 analizowanej ustawy przewiduje, że szpik lub komórki krwiotwórcze krwi obwodowej mogą być pobrane od małoletniego, który nie posiada pełnej zdolności do czynności prawnych, jedynie za zgodą przedstawiciela ustawowego po uzyskaniu zgody sądu opiekuńczego, właściwego ze względu na miejsce zamieszkania kandydata na dawcę, a w przypadku gdy dawcą szpiku jest małoletni powyżej lat 13, wymagana jest także jego zgoda. Dla takich przypadków ustawodawca wprowadził zatem wymóg podwójnej zgody - sądu opiekuńczego i przedstawiciela ustawowego, a nawet potrójnej zgody, jeśli małoletni ukończył 13 lat. Ponadto, w porównaniu do u.z.l., przesuwając granicę wieku, od którego małoletni może współdecydować o działaniach medycznych, znacznie rozszerzył autonomię małoletniego pacjenta ${ }^{38}$. Warto przy tym zauważyć, że zgoda małoletniego, który ukończył 13 lat, dotyczy jedynie pobrania szpiku, a nie sytuacji, gdy jest on dawcą komórek krwiotwórczych krwi obwodowej, co słusznie jest przedmiotem krytyki doktryny ${ }^{39}$.

Odmienne zasady wyrażania zgody przez małoletniego przewiduje również ustawa o publicznej służbie krwi. Zgodnie z art. 15 ust. 1 pkt 2 wspomnianej ustawy co do zasady kandydat na dawcę lub dawca krwi powinien mieć pełną zdolność do czynności prawych. Natomiast art. 15 ust. 2 przewiduje, że jeżeli przemawiają za tym względy fizjologiczne lub lecznicze, kandydatem na dawcę krwi lub dawcą krwi może zostać również osoba nieposiadająca pełnej zdolności do czynności prawnych, powyżej 17 roku życia. W takim przypadku zarówno małoletni jak i jego przedstawiciel ustawowy muszą wyrazić w obecności lekarza, w formie pisemnej zgodę na pobranie. Warto zauważyć, że do dnia 10 września

38 Zob. K.M. Zoń, Dopuszczalność transplantacji ex vivo od dawcy małoletniego w prawie polskim, [w:] J. Mazurkiewicz (red.), Księga dla naszych kolegów: prace prawnicze poświęcone pamięci doktora Andrzeja Ciska, doktora Zygmunta Masternaka i doktora Marka Zagrosika, Wrocław 2013, s. 498.

39 Zob. A. Sporczyk, Granice autonomii matoletniego żywego dawcy w transplantacji, „Białostockie Studia Prawnicze" 2017, t. 22, nr 2, s. 65. 
2016 r., jeśli przemawiały za tym względy fizjologiczne lub lecznicze, kandydatem na dawcę krwi na rzecz wstępnych, zstępnych i rodzeństwa mógł zostać również małoletni za pisemną zgodą jego przedstawiciela ustawowego i po wyrażeniu przez niego, wobec lekarza, zgody na pobranie. Jeśli jednak małoletni ukończył 13 lat, wówczas wymagana była tylko jego zgoda wyrażona w obecności jego przedstawiciela ustawowego lub opiekuna. W celu dostosowania polskiej regulacji prawnej do przepisów Unii Europejskiej ${ }^{40}$, ustawodawca uchwalił ustawę z dnia 20 maja 2016 r. o zmianie ustawy o publicznej służbie krwi oraz niektórych innych ustaw $^{41}$, którą zmienił m.in. warunki pobierania krwi lub jej składników.

\section{Zakończenie}

Oceniając obowiązujące przepisy prawne, regulujące zasady wyrażania przez małoletniego zgody na interwencję medyczną, w pierwszej kolejności należy zwrócić uwagę na to, iż ustawodawca nie zdecydował się unormować jednolicie wszystkich przypadków zgody na poszczególne świadczenia zdrowotne. Od reguł ogólnych, zawartych w u.z.l. i u.p.p., przewidział szereg wyjątków. Różnice sprowadzają się głównie do granicy wieku, od którego małoletniemu przysługuje prawo do wyrażenia zgody, oczywiście łącznie z przedstawicielem ustawowym. Zazwyczaj jest to granica 16 roku życia, ale zdarza się też, że możliwość decydowania przez małoletniego uzależniona jest od ukończenia przez niego 13 i 17 lat. Niewątpliwie nadmierna kazuistyka utrudnia poznanie i stosowanie poszczególnych przepisów.

Należy również podkreślić, że także sam fakt wprowadzenia przez ustawodawcę granicy wieku, od którego należy uwzględniać zgodę pa-

40 Dyrektywa 2002/98/WE Parlamentu Europejskiego i Rady z dnia 27 stycznia 2003 r. ustanawiającej normy jakości i bezpieczeństwa dla pobrania, badania, preparatyki, przechowywania i wydawania krwi ludzkiej i jej składników oraz wnoszącej poprawki do dyrektywy 2001/83/WE, Dz. Urz. UE L 33 z 08.02.2003; dyrektywa Komisji 2004/33/WE z dnia 22 marca 2004 r. wykonującej dyrektywę 2002/98/WE Parlamentu Europejskiego i Rady w zakresie niektórych wymagań technicznych dotyczących krwi i składników krwi, Dz. Urz. UE L 91 z 30.03.2004.

${ }^{41}$ Ustawa z dnia 20 maja 2016 r. o zmianie ustawy o publicznej służbie krwi oraz niektórych innych ustaw, Dz. U. z 2016 r. poz. 823. 
cjenta, jest przedmiotem ocen krytycznych doktryny. Podkreśla się, że takie schematyczne i sztywne podejście do problemu zgody pacjenta małoletniego, pomija zupełnie stopień jego rozeznania i może być dla wielu pacjentów krzywdzące. Szukając optymalnego modelu zgody pacjenta małoletniego na udzielnie świadczenia zdrowotnego, warto zwrócić uwagę na zasady wyrażania zgody na udział w eksperymencie medycznym. Wydaje się, że przyjęte przez ustawodawcę rozwiązanie uwzględniające nie tylko granicę wieku, ale także faktyczną zdolność pacjenta do zrozumienia i oceny sytuacji jest najlepsze ze wszystkich powyżej zaprezentowanych. Dlatego też warto rozważyć wprowadzenie do zasad ogólnych w u.z.l. i u.p.p. możliwości uwzględnienia zgody pacjenta, który nie ukończył 16 lat, a według opinii lekarza jest dostatecznie świadomy do wyrażenia zgody na udzielenie świadczenia zdrowotnego. Należy przy tym zwrócić uwagę, że także Kodeks Etyki Lekarskiej ${ }^{42}$, który wprawdzie nie stanowi źródła powszechnie obowiązującego prawa, ale dla lekarzy niewątpliwie wyznacza kierunek wykonywania praktyki lekarskiej, przewiduje w art. 15 ust. 2, że w przypadku osoby niepełnoletniej, lekarz powinien starać się uzyskać także jej zgodę, o ile jest ona zdolna do świadomego jej wyrażenia.

Słowa kluczowe: świadoma zgoda, małoletni pacjent, świadczenie zdrowotne

\section{Bibliografia}

Bołoz W., Geneza, ewolucja i etyczne uzasadnienie zasady "świadomej zgody", [w:] W. Bołoz, R. Krajewski (red.), Realizacja zasady informed consent w kontekście relacji lekarz-pacjent. Wyzwania i bariery rozwojowe w Polsce, Warszawa 2012, s. 32-42.

Czarkowski M., Zgoda na udziat w badaniach klinicznych osób niezdolnych do jej wyrażenia, „Prawo i Medycyna” 2014, nr 3/4, s. 91-106.

Dercz M., H. Izdebski, T. Rek, Dziecko - pacjent i świadczeniobiorca, Warszawa 2015. Drozdowska U., W. Wojtal, Zgoda i informowanie pacjenta, Warszawa 2010.

Dudzińska A., Zgoda na działanie medyczne, „Państwo i Prawo” 2009, z. 11, s. 69-79.

${ }^{42}$ Kodeks Etyki Lekarskiej, uchwalony przez II Krajowy Zjazd Lekarzy dnia 14 grudnia 1991 r., https://www.nil.org.pl/_data/assets/pdf_file/0003/.../Kodeks-Etyki-Lekarskiej [dostęp: 15.12.2018 r.]. 
Filar M., Postępowanie lecznicze (świadczenie zdrowotne) w stosunku do pacjenta niezdolnego do wyrażenia zgody, "Prawo i Medycyna” 2003, nr 13, s. 41-49.

Gałęska-Śliwka A., K. Śliwka, Zgoda małoletniego na udział w eksperymencie medycznym, "Archiwum Medycyny Sądowej i Kryminologii” 2008, t. 58, nr 4, s. 194-196.

Haberko J., Małoletni pacjent jako podmiot interesu prawnie chronionego w kontekście wybranych aspektów stosowania nowoczesnych technologii medycznych, [w:] O. Nawrot, A. Wnukiewicz-Kozłowska (red.), Temida w dobie rewolucji biotechnologicznej - wybrane problemy bioprawa, Gdańsk 2015, s. 43-54.

Karkowska D., Ustawa o prawach pacjenta i Rzeczniku Praw Pacjenta. Komentarz, Warszawa 2012.

Kędziora R., Problematyka zgody pacjenta w świetle polskiego ustawodawstwa medycznego, „Prokuratura i Prawo” 2003, nr 7/8, s. 41-61.

Malczewska M., Komentarz do art. 32 ustawy o zawodach lekarza i lekarza dentysty, [w:] E. Zielińska (red.), Ustawa o zawodach lekarza i lekarza dentysty. Komentarz, Warszawa 2014, s. 601-631.

Michałek-Janiczek A., Autonomia małoletniego w zakresie leczenia, „Państwo i Prawo" 2009, z. 10, s. 57-69.

Nesterowicz M., Prawo medyczne. Glosy i komentarze do orzeczeń sądowych, Warszawa 2012.

Nesterowicz M., Wyrok Sądu Apelacyjnego w Warszawie z dnia 31 marca 2006 r., I A Ca 973/05, LEX nr 252827, „Prawo i Medycyna” 2010, nr 2, s. 125-134.

Niemczyk S., A. Łazarska, Medyczno-prawne rozważania o konkretyzacji przedmiotu zgody pacjenta, „Prawo i Medycyna” 2008, nr 3, s. 65-81.

Olszewski B., Uniwersalna definicja dziecka?, "Przegląd Prawa i Administracji” 2011, nr 85, s. 205-217.

Rutkowski S., Zgoda na zabieg leczniczy w ujęciu art. 192 k.k., „Prokuratura i Prawo” 2000, nr 2, s. 15-30.

Sporczyk A., Granice autonomii małoletniego żywego dawcy w transplantacji, „Białostockie Studia Prawnicze" 2017, t. 22, nr 2, s. 57-68.

Świderska M., Glosa do wyroku Sądu Najwyższego z dnia 16 maja 2012, sygn. III CSK 227/11, LEX nr 1211885, „Prawo i Medycyna” 2012, nr 3/4, s. 246-252.

Świderska M., Zgoda Pacjenta na zabieg medyczny, Toruń 2007.

Zajączkowska M.J., Prawa dziecka, [w:] L. Koba, W. Wacławczyk (red.), Prawa człowieka. Wybrane zagadnienia i problemy, Warszawa 2009, s. 369-383.

Zoń K.M., Dopuszczalność transplantacji ex vivo od dawcy małoletniego w prawie polskim, [w:] J. Mazurkiewicz (red.), Księga dla naszych kolegów: prace prawnicze poświęcone pamięci doktora Andrzeja Ciska, doktora Zygmunta Masternaka i doktora Marka Zagrosika, Wrocław 2013, s. 489-502. 


\section{THE RIGHT OF A CHILD-PATIENT TO GIVE A CONSENT FOR A HEALTHCARE SERVICE}

\section{Summary}

A right to give a consent for a healthcare service is one of the most critical patients' rights, but yet in relation to children it is limited. The principle is that the minor patient who turned 16 agrees for medical activities together with it's legally designated representative; whereas for a patient who did not turn 16 decides exclusively the representative itself. For certain medical services Polish legislator introduced other rules. Differently regulated are rules concerning giving a consent by minor patients for participation in a medical experiment, for collection of the cells, tissues and organs for the purpose of transplantation, for taking blood or for a psychiatric examination. Excessive casuistry in accordance with the consent of a minor patient for a healthcare service undoubtedly make it's understanding and applying more difficult.

Key words: informed consent, minor patient, healthcare service

\section{ПРАВО ПАЦИЕНТА - РЕБЕНКА НА СОГЛАСИЕ НА ОКАЗАНИЕ МЕДИЦИНСКИХ УСЛУГ}

\section{Резюме}

Право дать согласие на предоставление медицинских услуг является одним из важнейших прав пациента, однако в отношении детей оно ограничено. Как правило, несовершеннолетний, достигший 16-летнего возраста, соглашается на медицинские действия вместе со своим законным представителем, в то время как о пациенте, не достигшем 16-летнего возраста, принимает решение только законный представитель. Однако для некоторых служб здравоохранения польский законодатель ввел другие правила. По-другому урегулировал правила согласия пациента на участие в медицинском эксперименте, для сбора клеток, тканей и органов для их трансплантации, для сбора крови или для психиатрического обследования. Чрезмерная казуистика положений о согласии несовершеннолетнего пациента на оказание медицинских услуг, несомненно, препятствует их познанию и применению.

Ключевые слова: информированное согласие, несовершеннолетний пациент, здравоохранение 